Vlatka Božić, mag. oec.*

Izv. prof. dr. sc. Petar Sorić ${ }^{* *}$

\title{
UČINCI PRELIJEVANJA NEIZVJESNOSTI EKONOMSKE POLITIKE IZMEĐU HRVATSKE I ODABRANIH TRGOVINSKIH PARTNERA
}

\section{ECONOMIC POLICY UNCERTAINTY SPILLOVER EFFECTS BETWEEN CROATIA AND SELECTED TRADE PARTNERS}

SAŽETAK: U ovome radu analizirani su učinci prelijevanja ekonomske neizvjesnosti između Hrvatske i njezinih odabranih trgovinskih partnera - Njemačke, Italije, SAD-a, Francuske, Španjolske, Rusije i Švedske. Temeljni cilj ovog rada jest istražiti kojim se zemljama u najvećoj mjeri može pripisati prelijevanje šokova u ekonomskoj neizvjesnosti na Hrvatsku. Za male, otvorene ekonomije kao što je i Hrvatska, takvi učinci prelijevanja od velikog su interesa i važnosti jer su vrlo izložene potencijalnom riziku. Empirijska analiza provedena je pomoću vektorskog autoregresijskog modela i Diebold-Yilmazova indeksa prelijevanja. Rezultati empirijske analize pokazali su da je više od dvije petine varijance prognostičke pogreške promatranog uzorka objašnjeno prelijevanjima šokova u ekonomskoj neizvjesnosti između danih zemalja. Od svih promatranih ekonomija, najveći neto prenositelj šokova je SAD. S druge strane, najveći neto primatelji šokova su Rusija i Hrvatska.

KLJUČNE RIJEČI: indeks prelijevanja, ekonomska neizvjesnost, vektorski autoregresijski (VAR) model

ABSTRACT: This paper analyzes the spillover effects of economic uncertainty between Croatia and its selected trading partners - Germany, Italy, USA, France, Spain, Russia and Sweden. The main goal of this paper is to investigate which countries are most accountable for the spillover of shocks in economic uncertainty to Croatia. For small open economies, such as Croatia, such spillover effects are of great interest and importance, as they are highly exposed to potential risk. The empirical analysis was performed using a vector autoregressive model and a Diebold-Yilmaz Spillover Index. Based on the conducted empirical analysis, it is concluded that more than two-fifths of the forecast error variance of

\footnotetext{
* Vlatka Božić, mag. oec., Sportening, Kuzminečka 10, 10000 Zagreb, Hrvatska

** Izv. prof. dr. sc. Petar Sorić, Ekonomski fakultet u Zagrebu, Trg J. F. Kennedyja 6, 10000 Zagreb, Hrvatska
} 
the observed sample is explained by spillover shocks in economic uncertainty between the observed countries. Of all the countries observed, the United States are the largest net transmitter of shocks. On the other hand, the largest net recipients of shocks are Russia and Croatia.

KEY WORDS: spillover index, economic policy uncertainty, vector autoregressive model

\section{UVOD}

Globalizacija je nacionalne ekonomije učinila povezanijima, što može dovesti do višeslojnih i dalekosežnih problema, kao što se moglo vidjeti iz globalne financijske krize ili recentne koronakrize. Naizgled nepovezan događaj u jednoj zemlji ili sektoru može se prenijeti u drugu zemlju ili sektor, gdje su učinci šokova potencijalno trajni te mogu biti dodatno naglašeni drugim šokovima.

Tema ovog rada jest prelijevanje ekonomske neizvjesnosti između Hrvatske i odabranih trgovinskih partnera (Francuske, Italije, Njemačke, Španjolske, Švedske, Rusije i SAD-a). Temeljni cilj rada jest istražiti koje su zemlje, među odabranim trgovinskim partnerima Hrvatske, najviše zaslužne za prelijevanje šokova u ekonomskoj neizvjesnosti na Hrvatsku. Očekivani doprinos ovog rada jest u proučavanju učinaka prelijevanja između zemalja koje imaju jake trgovinske veze s Hrvatskom, a do sada se nisu promatrale zajedno, korištenjem relativno novije metodologije - Diebold-Yilmazova indeksa prelijevanja (engl. Diebold-Yilmaz Spillover Index). Navedena metodologija primijenit će se kako bi se na adekvatan način uzela u obzir međusobna ekonomska povezanost promatranih zemalja te kako bi se analiziralo prelijevanje šokova u ekonomskoj neizvjesnosti među zemljama u uzorku.

Rad je strukturiran na sljedeći način. U narednom poglavlju dan je pregled literature i dosadašnjih empirijskih istraživanja o prelijevanju šokova. Treći dio bavi se ekonomskom neizvjesnošću. Četvrto poglavlje prikazuje metodološki okvir istraživanja, a peto poglavlje prezentira dobivene empirijske rezultate. U posljednjem će se poglavlju dati relevantni zaključci o učincima prelijevanja ekonomske neizvjesnosti za promatrane zemlje i sumirati najvažnije implikacije dobivenih rezultata.

\section{PREGLED LITERATURE I DOSADAŠNJIH EMPIRIJSKIH ISTRAŽIVANJA}

Šokovi se mogu prenijeti različitim kanalima, kako na makro- tako i na mikrorazini. U nastavku će se dati kratak pregled empirijskih istraživanja na temu prelijevanja šokova u poslovnim ciklusima.

\subsection{Prelijevanje šokova u poslovnim ciklusima}

Dosadašnja istraživanja prelijevanja šokova u poslovnim ciklusima uglavnom su fokusirana na visokorazvijene zemlje. Tako, primjerice, Yilmaz (2009) analizira međunarodno prelijevanje poslovnih ciklusa u G6 skupini zemalja koristeći se metodologijom indeksa prelijevanja na mjesečnim indeksima industrijske proizvodnje. Indeks prelijevanja ukazuje 
na značajne varijacije u razdobljima naftnih šokova 1970-ih i 1980-ih, tijekom recesije dotcom početkom 2000-ih, a posebno u razdoblju globalne financijske krize 2007. godine.

Arčabić i Škrinjarić (2019) analiziraju prelijevanje i sinkronizaciju poslovnih ciklusa starih članica Europske unije (EU), koji su važni za EU, a posebno za eurozonu kako bi se izbjegli asimetrični šokovi i problemi u zajedničkoj monetarnoj politici. U svojoj analizi koriste se metodologijom indeksa prelijevanja Diebolda i Yilmaza (2012) na uzorku od 15 starih članica EU-a u periodu od 1975. do 2018. godine. Rezultati pokazuju da prelijevanja poslovnih ciklusa naglo rastu tijekom razdoblja između 2009. i 2015. godine, što se podudara s razdobljem financijske krize i krize državnog duga u eurozoni.

Prepoznajući značaj tržišta u nastajanju (engl. Emerging Markets; EM), Huidrom et al. (2019) analiziraju prelijevanje šokova u rastu između zemlja EM-a - Kine, Rusije, Indije, Brazila, Turske, Meksika i Indonezije, jer njihov BDP čini $80 \%$ ukupnog BDP-a tržišta u nastajanju. U svojoj analizi promatraju učinke prelijevanja koristeći se bayesijanskim VAR modelom. Rezultati analize pokazuju da su prelijevanja iz EM-a značajna (povećanje rasta EM-a za 1 postotni bod povezano je s povećanjem rasta od 0,9 postotnih bodova u drugim tržištima u nastajanju te povećanjem globalnog rasta za 0,6 postotnih bodova nakon tri godine). Međutim, koliko god bila značajna, prelijevanja iz EM-a još su uvijek manja od onih iz zemalja G7. Bitan zaključak je i da su, među EM-om, prelijevanja iz Kine najveća i prožimaju se globalno.

Gupta et al. (2020) koriste se nedavno kreiranom mjerom neizvjesnosti kamatnih stopa (engl. Interest Rate Uncertainty) kako bi istražili neizvjesnost monetarne politike u deset razvijenih zemalja u vremenskoj i frekvencijskoj domeni. Najveći indeksi prelijevanja posljedica su inovacija u samoj zemlji; međutim, postoje neki slučajevi gdje su i indeksi prelijevanja između zemalja razmjerno veliki. Ti se odnosi mijenjaju s vremenom i uočene su velike razlike u direktnom prelijevanju tijekom globalne financijske krize. Većina volatilnosti ograničena je na krizno razdoblje. Kreatori politike trebali bi računati na prelijevanja iz SAD-a, Njemačke, Francuske i Španjolske jer je iz analize vidljivo da su oni glavni neto prenositelji neizvjesnosti monetarne politike.

S obzirom na to da citirane studije ukazuju na značajne efekte prelijevanja u međunarodnim ekonomskim tokovima, pri čemu su zemlje u razvoju uglavnom neto primatelji šokova, za pretpostaviti je da su slični obrasci na djelu i u hrvatskom gospodarstvu. Sljedeće poglavlje daje kratak pregled literature o utjecaju vanjskih šokova na hrvatsko gospodarstvo.

\subsection{Utjecaj vanjskih šokova na hrvatsko gospodarstvo}

Hrvatsku se može opisati kao malo, otvoreno i visoko eurizirano gospodarstvo s upravljanim tečajem i slobodnim tokovima kapitala. Takve su karakteristike vrlo važne u kontekstu ekonomske politike jer određuju manevarski prostor i mogućnosti kreatora politika za postizanje glavnih ekonomskih ciljeva (Ćorić, Šimović i Deskar-Škrbić 2015).

Kao malo, otvoreno gospodarstvo, Hrvatsku karakterizira otvorenost tržišta, a takva su gospodarstva osjetljiva na zbivanja u inozemstvu, odnosno inozemne šokove. Gospodarska aktivnost u malim, otvorenim gospodarstvima kao što je hrvatsko u velikoj mjeri ovisi o makroekonomskoj situaciji u okruženju. Prijašnja su istraživanja ukazala na nedvojben 
utjecaj poslovnih, fiskalnih i monetarnih šokova razvijenih zemalja na susjedna, uglavnom mala i otvorena gospodarstva (Nadoveza i Šimurina 2012).

U slučaju Hrvatske posebno je važno pitanje okruženja zbog problema malog, otvorenog gospodarstva (Arčabić 2020). Iz tog će se razloga empirijskom dijelu ovog rada u analizu, osim Hrvatske, uključiti i njezini bitni vanjskotrgovinski partneri, a u ovom poglavlju prikazat će se dosadašnji radovi koji obrađuju utjecaj vanjskih šokova na hrvatsko gospodarstvo.

Krznar i Kunovac (2010) istražuju kolika je relativna važnost inozemnih u odnosu na domaće čimbenike za varijaciju te kretanje domaće inflacije i BDP-a. Rezultati procijenjenog VAR modela s restrikcijama blok-egzogenosti (za inozemne varijable) pokazuju da postoji značajan učinak prelijevanja promjene svjetskih cijena na indekse proizvođačkih i potrošačkih cijena. Svjetske cijene objašnjavaju najveći dio varijacije domaćih cijena. Pored toga, domaća gospodarska aktivnost, čija se kolebljivost može objasniti šokovima inozemnog BDP-a, gotovo uopće ne objašnjava varijaciju domaćih cijena. S druge strane, šokovi BDP-a EU-a glavna su determinanta reakcije domaće gospodarske aktivnosti, kao i glavni izvor fluktuacija hrvatskog BDP-a.

Jovančević, Arčabić i Globan (2012) analiziraju prijenos poslovnih ciklusa iz EU-a na hrvatsko gospodarstvo te promatraju dolazi li do promjene intenziteta prijenosa poslovnih ciklusa tijekom promatranog razdoblja od 1997. do 2010. godine. Dobiveni rezultati pokazuju da je Hrvatska vrlo osjetljiva na gospodarske poremećaje iz inozemstva i da je intenzitet prijenosa poslovnih ciklusa dodatno rastao krajem promatranog razdoblja.

Nadoveza i Šimurina (2012) VAR metodom ukazuju na osjetljivost malih, otvorenih ekonomija Srednje i Istočne Europe na eksterne šokove potražnje. Također, rezultati njihove analize upućuju na negativan odgovor BDP-a Hrvatske na jedinični šok rasta udjela javnog duga u BDP-u Njemačke.

Kunovac (2013) analizira utjecaj prelijevanja vanjskih šokova na trošak zaduživanja te pokazuje da je primijenjena mjera prelijevanja i zaraze bila dominantan faktor pri objašnjavanju premije za rizik tijekom recentne krize javnih financija. Njegova analiza pokazuje da su tijekom financijske krize 2008. godine zemlje Srednje i Istočne Europe bile ključni izvor prelijevanja i zaraze za europske spreadove. $\mathrm{S}$ druge strane, glavni izvori prelijevanja i zaraze tijekom recentne krize javnih financija su Portugal, Italija, Irska, Grčka i Španjolska. U tom je razdoblju važnost fundamenata značajno porasla za Hrvatsku, koja je uz Mađarsku na cijelom uzorku imala najniži udio fundamenata u ukupnoj varijanci.

Škrinjarić i Šego (2019) procjenjuju prelijevanje rizika između odabranih tržišta kapitala Srednje, Istočne i Jugoistočne Europe kako bi se uvidjele mogućnosti međunarodne diversifikacije portfelja. U analizi se koriste VAR modelom te Diebold-Yilmazovim (2012) indeksom prelijevanja, s procijenjenim indeksima tijekom vremena (princip pomičnih prozora) kako bi se promatrala dinamika, što je važno za strategije ulaganja. Koriste se mjesečnim podacima o burzovnim indeksima za period od 2012. do 2019. godine. Rezultati pokazuju da su neke zemlje bile neto izvoznici šokova u sustavu (Slovenija i Češka), dok su neke neto primatelji (Hrvatska i Ukrajina).

U posljednje gotovo dvije godine svjedočili smo utjecaju vanjskih šokova na hrvatsko gospodarstvo izazvano koronavirusom. Koronakriza je rezultat primarno četiriju šokova: zdravstvenog šoka, koji se može okarakterizirati kao šok ponude, šoka potražnje, šoka negativnih očekivanja i visoke neizvjesnosti, te posljednjeg, potencijalnog šoka loših mjera 
ekonomske politike (Čavrak 2020). U svom radu Arčabić (2020) radi indirektnu usporedbu koronakrize s tranzicijskom recesijom te globalnom financijskom krizom. Proučava efekte inozemnog i domaćeg šoka na dodanu vrijednost prema područjima Nacionalne klasifikacije djelatnosti (NKD) korištenjem modela strukturne vektorske autoregresije (SVAR), te analizira utjecaj koronakrize na tekuće pokazatelje tržišta rada. Pored toga, analizira se kako sektori međusobno djeluju jedan na drugi te postoje li međusobna prelijevanja. Rezultati pokazuju da je rast nezaposlenosti na samome početku koronakrize brži nego u prethodnim dvjema recesijama, ali se ubrzo stabilizirao. Također, utvrđeno je da su brojni sektori izrazito osjetljivi na inozemni šok, dok je osjetljivost na domaće šokove nešto slabije izražena.

\section{EKONOMSKA NEIZVJESNOST}

Ekonomska neizvjesnost u Knightovu smislu karakterizirana je nemogućnošću ekonomskih subjekata da anticipiraju buduće događaje ili procijene vjerojatnosti njihovih nastupanja (Sorić i Lolić 2017). Vjeruje se da je povećana neizvjesnost ključan razlog koji pridonosi slabljenju globalnog gospodarskog rasta posljednjih godina. Konkretno, smatra se da je niz geopolitičkih i ekonomskih šokova, poput krize europskog državnog duga i referenduma o Brexitu, povećao neizvjesnost ekonomske politike, što je utjecalo na privatnu domaću potražnju u mnogim gospodarstvima. Jedno od prirodnih pitanja za makroekonomiste i kreatore politike u cijelom svijetu jest utječu li i u kojoj mjeri šokovi u neizvjesnosti ekonomske politike u jednoj zemlji na neizvjesnost ekonomske politike i na poslovni ciklus u drugoj zemlji (Luk et al. 2018). Globalni indeks ekonomske neizvjesnosti dosegao je povijesni maksimum pojavom koronakrize (Baker, Bloom i Davis, 2021), što daje dodatnu motivaciju za modeliranje indeksa te analizu učinaka prelijevanja istoga.

\subsection{Indeks ekonomske neizvjesnosti}

Tijekom povijesti neizvjesnost se mjerila na više načina. Neki od pokazatelja su indeks neizvjesnosti ekonomske politike (Baker, Bloom i Davis 2016), Economistov recesijski indeks te neslaganje ekonomskih subjekata kao mjera neizvjesnosti (Sorić i Lolić 2017). U ovome radu kao mjera neizvjesnosti primijenit će se indeks neizvjesnosti ekonomske politike (engl. Economic Policy Uncertainty Index; EPU indeks).

Kako bi mjerili ekonomsku neizvjesnost, Baker, Bloom i Davis (2016) konstruirali su EPU indeks, sačinjen od triju različitih komponenti.

Prva komponenta bazirana je na frekvenciji novinskih članaka u deset vodećih američkih dnevnih novina koji problematiziraju ekonomsku neizvjesnost. Konkretno, da bi se članak uzeo u obzir, mora sadržavati kombinaciju barem triju riječi iz unaprijed definiranih skupina pojmova: ekonomska (engl. economic), politika (engl. policy) i neizvjesnost (engl. uncertainty).

Druga komponenta je broj poreznih odredbi čija zakonska primjena istječe u narednih deset godina, a prati se na mjesečnoj razini.

Treća komponenta promatra neizvjesnost kao mjeru neslaganja u prognozama dobivenu iz ankete profesionalnih prognostičara (engl. Survey of Professional Forecasters). 
Konačna procjena EPU indeksa na mjesečnoj razini dobije se ponderiranjem pojedinačnih komponenata indeksa. Ponder od $1 / 2$ dodjeljuje se indeksu neizvjesnosti baziranom na novinskim člancima, dok se ponder od $1 / 6$ dodjeljuje za porezni indeks neizvjesnosti, razlike u pogledu makroekonomskih prognoza i razlike u pogledu potrošnje na različitim razinama vlasti.

Hrvatska verzija EPU indeksa temelji se isključivo na medijskim izvještajima o neizvjesnosti, dok preostale dvije komponente izvornog EPU indeksa nisu uključene zbog nedostupnosti podataka (Sorić i Lolić 2017). Indeksi za ostale zemlje koje se promatraju u empirijskoj analizi konstruirani su na sličan način.

\subsection{Prelijevanje ekonomske neizvjesnosti}

U ovome dijelu rada dan je pregled empirijskih radova o šokovima u ekonomskoj neizvjesnosti, povezanosti neizvjesnosti i ekonomske aktivnosti te prelijevanju ekonomske neizvjesnosti između pojedinih zemalja.

Istraživanje uloge neizvjesnosti u realnoj ekonomiji i različitih ekonomskih politika u objašnjavanju prinosa na tržištima kapitala postalo je popularno među makroekonomistima i financijskim ekonomistima jer ekonomska neizvjesnost i različite gospodarske politike mogu utjecati na ponašanje sudionika na tržištu kapitala i robnom tržištu. Primjerice, kada poduzeća, potrošači i ulagači nerado donose odluke o potrošnji i ulaganjima, to može negativno utjecati na zdravlje cjelokupnog gospodarstva. S velikom neizvjesnošću u gospodarstvu, tvrtke će vjerojatno odgoditi ulaganje u potencijalne investicijske projekte i obustaviti zapošljavanje novih radnika. Takve odluke mogu potaknuti ili produbiti recesiju. Motiviran time, Sum (2012) istražuje učinak promjena ekonomske neizvjesnosti na performanse burzi u EU-u, Hrvatskoj, Norveškoj, Rusiji, Švicarskoj, Turskoj i Ukrajini. Analizom mjesečnih prinosa na glavne burzovne indekse u tim zemljama od 1993. do 2012. godine i EPU indeksa, Sum (2012) zaključuje da promjene u ekonomskoj neizvjesnosti negativno utječu na prinose u većini promatranih zemalja.

Škrinjarić i Orlović (2020) procjenjuju učinke prelijevanja šokova u ekonomskoj neizvjesnosti te prinose i rizike na burzama zemalja Srednje i Istočne Europe. Rezultati pokazuju da su najveća prelijevanja između rizika, prinosa i EPU indeksa pronađena u Češkoj, Litvi, Sloveniji i Poljskoj, što znači da burze u spomenutim zemljama mnogo više reagiraju na promjene EPU-a u odnosu na ostatak promatranog uzorka.

Šokovi neizvjesnosti sve se češće ističu kao novi uzroci poslovnih ciklusa. Arčabić (2015) tako proučava makroekonomsko djelovanje neizvjesnosti u Republici Hrvatskoj. Rezultati pokazuju da kućanstva i poduzeća reagiraju na neizvjesnost smanjenjem štednje i zaduživanja, dok država najprije pokušava djelovati preventivno povećavajući štednju i smanjujući zaduživanje, zatim nakon šest mjeseci dolazi do promjene trenda te se štednja države smanjuje, a zaduživanje povećava.

Colombo (2013) istražuje učinke šokova neizvjesnosti ekonomske politike SAD-a na odabrane makroekonomske agregate u eurozoni koristeći se SVAR metodologijom. Rezultati pokazuju da šok od jedne standardne devijacije u ekonomskoj neizvjesnosti SAD-a dovodi do statistički značajnog pada europske industrijske proizvodnje $(-0,12$ $\%)$ i cijena $(-0,06 \%)$. Također, pokazalo se da je doprinos šoka neizvjesnosti SAD-a 
europskim agregatima kvantitativno veći od doprinosa šoka neizvjesnosti specifičnog za eurozonu.

Balcilar et al. (2017) ispituju ulogu neizvjesnosti ekonomske politike SAD-a u učinkovitosti monetarne politike u eurozoni. Koristeći se strukturnim IVAR modelom (engl. Interacted Vector Autoregression), otkrivaju da neizvjesnosti u vezi s promjenama politike u SAD-u umanjuje učinak šokova monetarne politike u eurozoni, pri čemu cijene i proizvodnja značajnije reagiraju na šokove monetarne politike kada je razina neizvjesnosti u SAD-u niska.

Gabauer i Gupta (2018) prikazuju važnost prelijevanja neizvjesnosti monetarne politike te otkrivaju da je neizvjesnost monetarne politike glavni pokretač EPU-a, nakon čega slijede fiskalna, zatim valutna i na kraju neizvjesnost trgovinske politike. Rezultati istraživanja Yina i Hana (2014) pokazuju pak da učinci prelijevanja makroekonomske neizvjesnosti u velikim gospodarstvima nemaju nikakav trend, nego jasne skokove i dosežu svoj vrhunac tijekom globalne financijske krize 2008. godine.

Čižmešija, Lolić i Sorić (2017) daju procjenu Toda-Yamamotova testa uzročnosti između EPU indeksa i ekonomske aktivnosti u SAD-u, Francuskoj, Njemačkoj, Italiji, Španjolskoj i UK-u. Rezultati pokazuju da uzročnost ide u obama smjerovima samo za SAD, dok u jednom smjeru ide samo za Francusku i Njemačku. U cijelom promatranom periodu pokazalo se da ekonomska aktivnost uzrokuje ekonomsku neizvjesnost u Grangerovu smislu u Njemačkoj, dok je veza suprotnog smjera za Francusku.

Škrabić Perić i Sorić (2018) ispituju prediktivnu sposobnost EPU indeksa s obzirom na ukupnu ekonomsku aktivnost u trinaest zemalja. U analizi se koriste heterogenim panel Grangerovim testom uzročnosti. Rezultati pokazuju da EPU indeks uzrokuje ekonomsku aktivnost u Grangerovu smislu samo u Japanu, Koreji i Indiji. To se djelomično može objasniti negativnom pristranošću medija i mogućim metodološkim manjkavostima pristupa konstruiranju EPU indeksa.

\section{EMPIRIJSKA ANALIZA UČINAKA PRELIJEVANJA EKONOMSKE NEIZVJESNOSTI IZMEĐU HRVATSKE I ODABRANIH TRGOVINSKIH PARTNERA}

\subsection{Opis metodologije}

U ovome radu promatrat će se učinci prelijevanja ekonomske neizvjesnosti između Hrvatske i njezinih odabranih trgovinskih partnera. Glavni je cilj istražiti je li neizvjesnost u jednoj zemlji pod značajnim utjecajem šokova u ekonomskoj neizvjesnosti u ostalim promatranim zemljama. Pored navedenog, cilj je uvidjeti jesu li promatrane zemlje neto primatelj ili neto prenositelj neizvjesnosti, kao i saznati ukupnu razinu učinka prelijevanja u promatranom uzorku zemalja.

Kako bi se postigli ciljevi rada, primijenit će se metodologija prelijevanja šokova, mjerena indeksima prelijevanja, koju su razvili Diebold i Yilmaz (2009, 2012). Metodologija se usredotočuje na mjerenje direktnih prelijevanja u generaliziranom VAR okviru, koji eliminira moguću ovisnost rezultata o redoslijedu varijabli u modelu. 
Razmotrimo $\operatorname{VAR}(p)$ model od N varijabli:

$$
x_{t}=\sum_{i=1}^{p} \Phi_{i} x_{t-i}+\varepsilon_{t},
$$

gdje je $x_{t}$ vektor varijabli sustava, $\varepsilon \sim(0, \Sigma)$ je vektor slučajne varijable, te vrijedi da je $E\left(\varepsilon_{t}\right)$ $=0, E\left(\varepsilon_{t} \varepsilon_{t}^{\prime}\right)=\Sigma_{\varepsilon}<\infty$ i za $t \neq s E\left(\varepsilon_{t} \varepsilon_{s}^{\prime}\right)=0$.

Koeficijenti pomičnog prosjeka (ili transformacije, poput funkcija impulsnog odziva ili dekompozicije varijance) ključni su za razumijevanje dinamike sustava. Ova analiza, prema metodologiji Diebolda i Yilmaza (2012), oslanja se na dekompozicije varijance koje omogućuju raščlanjivanje varijance prognostičke pogreške svake varijable u dijelove koji se mogu pripisati različitim šokovima sustava. Dekompozicije varijance omogućuju procjenjivanje udjela varijance pogreške $H$ koraka unaprijed u prognoziranju $x_{i}$, koje je posljedica šoka u $x_{j}, \forall j \neq i$, za svaki $i$. MA reprezentacija modela je:

$$
x_{t}=\sum_{i=0}^{\infty} A_{i} \varepsilon_{t-i},
$$

gdje $N \times N$ matrice koeficijenata $A_{i}$ slijede rekurziju:

$$
A_{i}=\Phi_{1} A_{i-1}+\Phi_{2} A_{i-2}+\cdots+\Phi_{p} A_{i-p},
$$

pri čemu je $A_{0}$ matrica identiteta $N \times N$ s $A_{i}=0$ za $i<0$, a $\Phi_{1} \ldots \Phi_{p}$ su matrice parametara jednadžbe (3).

Izračun dekompozicije varijance zahtijeva ortogonalne inovacije, dok su VAR inovacije prema ovoj metodologiji generalno istodobno povezane. Identifikacijske sheme poput one temeljene na faktorizaciji Choleskog postižu ortogonalnost, ali dekompozicije varijance tada ovise o redoslijedu varijabli. Ovaj problem rješava se primjenom generaliziranog VAR okvira (Koop, Pesaran i Potter 1996), koji rezultira dekompozicijama varijance invarijantnima na poredak varijabli (matematički dokaz invarijantnosti na poredak varijabli moguće je pronaći u Pesaran i Shin 1998: 20)). Umjesto pokušaja ortogonalizacije šokova, generalizirani pristup dopušta korelirane šokove, ali ih na odgovarajući način uzima u obzir koristeći se povijesno promatranom raspodjelom pogrešaka. Budući da šokovi svake varijable nisu ortogonalizirani, zbroj doprinosa varijanci prognostičke pogreške, odnosno zbroj redaka elemenata tablice dekompozicije varijance nije nužno jednak jedan.

Definirani su vlastiti udjeli varijance, kao udjeli varijance pogreške $H$ koraka unaprijed u predviđanju $x_{i}$, koje su posljedica šokova u $x_{i}$, za $i=1,2, \ldots, N$ te prelijevanja, kao udjeli varijance pogreške $H$ koraka unaprijed u predviđanju $x_{i}$, koji su posljedica šokova na $x_{j}$, za $i, j=1,2, \ldots, \mathrm{N}$, tako da je $i \neq j$.

Ako se dekompozicija varijance prognostičke pogreške za $H$ koraka unaprijed označi s $\theta_{i j}^{g}(H)$, za $H=1,2, \ldots$, tada vrijedi:

$$
\theta_{i j}^{g}(H)=\frac{\sigma_{j j}^{-1} \sum_{h=0}^{H-1}\left(e_{i}^{\prime} A_{h} \sum e_{j}\right)^{2}}{\sum_{h=0}^{H-1}\left(e_{i}^{\prime} A_{h} \sum A_{h}^{\prime} e_{i}\right)},
$$


gdje je $\Sigma$ matrica varijance za vektor slučajne varijable $\varepsilon, \sigma_{j j}$ je standardna devijacija slučajne pogreške za $j$-tu jednadžbu, a $e_{i}$ je selekcijski vektor, s vrijednosti jedan za $i$-ti element, te vrijednosti nula za ostale elemente vektora.

Kako bi se koristile informacije dostupne u matrici dekompozicije varijance u izračunu indeksa prelijevanja, svaki unos matrice normalizira se zbrojem retka kao:

$$
\tilde{\theta}_{i j}^{g}(H)=\frac{\theta_{i j}^{g}(H)}{\sum_{j=1}^{N} \theta_{i j}^{g}(H)}
$$

Koristeći se doprinosima volatilnosti iz dekompozicije varijance, može se konstruirati ukupan indeks prelijevanja volatilnosti:

$$
S^{g}(H)=\frac{\sum_{\substack{i, j=1 \\ i \neq j}}^{N} \widetilde{\theta}_{i j}^{g}(H)}{\sum_{i, j=1}^{N} \widetilde{\theta}_{i j}^{g}(H)} \cdot 100=\frac{\sum_{\substack{N, j=1 \\ i \neq j}}^{N} \widetilde{\theta}_{i j}^{g}(H)}{N} \cdot 100 .
$$

Indeks ukupnog prelijevanja mjeri doprinos prelijevanja šokova volatilnosti u svim promatranim tržištima/zemljama ukupnoj varijanci prognostičke pogreške.

Generalizirani VAR pristup omogućuje i prikazivanje informacija o smjeru prelijevanja volatilnosti između zemalja. Direktna prelijevanja volatilnosti koje tržište $i$ primi sa svih ostalih tržišta $j$ mjere se kao:

$$
S_{i \cdot}^{g}(H)=\frac{\sum_{j=1}^{N} \widetilde{\theta}_{i j}^{g}(H)}{\sum_{i, j=1}^{N} \widetilde{\theta}_{i j}^{g}(H)} \cdot 100=\frac{\sum_{\substack{j=1 \\ j \neq i}}^{N} \widetilde{\theta}_{i j}^{g}(H)}{N} \cdot 100 .
$$

Na sličan način mjeri se prelijevanje direktne volatilnosti koje tržište $i$ prenosi na sva druga tržišta $j$ kao:

$$
S_{\cdot i}^{g}(H)=\frac{\sum_{\substack{j \neq 1 \\ j \neq i}}^{N} \widetilde{\theta}_{j i}^{g}(H)}{\sum_{i, j=1}^{N} \tilde{\theta}_{j i}^{g}(H)} \cdot 100=\frac{\sum_{\substack{j=1 \\ j \neq i}}^{N} \widetilde{\theta}_{j i}^{g}(H)}{N} \cdot 100 .
$$

Neto prelijevanje volatilnosti s tržišta $i$ na sva ostala tržišta $j$ računa se kao razlika između šokova prenesenih na sva ostala tržišta i onih primljenih sa svih ostalih tržišta:

$$
S_{i}^{g}(H)=S_{\cdot i}^{g}(H)-S_{i \cdot}^{g}(H)
$$

\subsection{Opis korištenih podataka}

Središnja varijabla u ovom radu je EPU indeks, dobiven prema metodologiji Baker, Bloom i Davis (2016) za osam analiziranih zemalja. Početni kriterij za odabir zemalja za analizu bio je prikupiti što duži niz podataka za što više zemalja koji zadovoljavaju uvjet da je udio izvoza u ukupnom izvozu Hrvatske veći od $1 \%$. Budući da nisu sve zemlje koje 
zadovoljavaju taj uvjet imale podatke za dovoljno dugačak period (ili podaci uopće nisu bili dostupni za pojedinu zemlju), odlučeno je da se nađe balans između broja zemalja u uzorku i duljine vremenskog niza. Ograničenje istraživanja izostanak je kontrolnih varijabli u razmatranom modelu. U konačnici su odabrane sljedeće zemlje prema dostupnosti podataka o EPU indeksu: Hrvatska, Njemačka, Italija, Francuska, Rusija, Španjolska, Švedska i SAD. Time je skup podataka za analizu razmatran u razdoblju od siječnja 2003. do ožujka 2021. godine. ${ }^{1}$

Empirijska analiza provedena je korištenjem programskog jezika $\mathrm{R}$, $\mathrm{u}$ integriranom razvojnom okruženju RStudio. U analizi su korišteni paketi vars, frequencyConnectedness, forecast, strucchange i e1071.

U nastavku rada koristit će se akronimima zemalja za EPU indeks pojedinih zemalja, i to kako slijedi: CRO = Hrvatska, GER = Njemačka, ITA = Italija, USA = Sjedinjene Američke Države, FRA = Francuska, SPA = Španjolska, RUS = Rusija i SWE = Švedska.

\section{REZULTATI EMPIRIJSKE ANALIZE}

Prvi korak analize bila je korelacijska analiza promatranih vremenskih nizova, koja je ukazala na relativno visoku, pozitivnu korelaciju EPU indeksa između promatranih zemalja, što je autorima dalo dodatnu motivaciju za proučavanje indeksa prelijevanja.

Svi vremenski nizovi desezonirani su korištenjem funkcije seasadj, koja iz vremenskog niza isključuje sezonsku komponentu. Budući da je iz svih grafikona vidljivo da se volatilnost povećava tijekom vremena, prije daljnje analize podaci su logaritmirani kako bi se stabilizirala varijanca nizova. Pored toga, zbog prisutnosti trenda prije nastavka analize, uklonjena je trend komponenta nizova.

Prije procjene VAR modela provedeni su prošireni Dickey-Fullerovi testovi o postojanju jediničnog korijena (engl. Augmented Dickey-Fuller test; ADF test), pokazavši kako su svi nizovi stacionarni.

Optimalan broj pomaka $p$ u $\operatorname{VAR}(p)$ modelu prema informacijskom kriteriju Akaikea, Hannan-Quinna i Schwartza (istodobno vodeći računa o autokorelaciji grešaka relacije) je dva. Stoga je ocijenjen VAR(2) model, tj. u svakoj su jednadžbi sustava kao regresori korištena dva pomaka EPU indeksa svih zemalja u uzorku. Provedeni su standardni dijagnostički testovi (Ljung-Boxov test o multivarijatnoj autokorelaciji, Jarque-Berin test normalnosti grešaka relacije, ARCH-LM-ov test autoregresivne uvjetne heteroskedastičnosti te OLS CUSUM-ov test stabilnosti modela) ${ }^{2}$. VAR(2) model pri $5 \%$ signifikantnosti zadovoljava sve standardne pretpostavke osim normalnosti grešaka relacije. Izračun indeksa prelijevanja u nastavku rada temelji se na inovacijskoj analizi, za koju pak normalnost grešaka relacije nije nužan uvjet (Lane i Lütkepohl 2010; Lütkepohl 2011), pa je empirijski dio rada nastavljen s VAR(2) modelom.

\footnotetext{
U analizu nije uključeno Ujedinjeno Kraljevstvo jer VAR model, koji uključuje i tu zemlju, nije mogao biti ocijenjen bez postojanja problema multivarijatne heteroskedastičnosti i autokorelacije grešaka relacije. Detaljni rezultati svih procjena i testova prije izračuna samih indeksa prelijevanja nisu prezentirani zbog prostornih ograničenja.
} 
Nastavak analize započinje pružanjem cjelovite analize prelijevanja ekonomske neizvjesnosti od siječnja 2003. do ožujka 2021. godine. U Tablici 1. dana je procjena ukupnog indeksa prelijevanja (relacija 6) u donjem desnom kutu, kao i svih komponenti varijance prognostičke pogreške za zemlju $i$ koje dolaze iz zemlje $j$, za sve $i$ i $j$. Njezin $i j$-ti unos procijenjen je doprinos varijanci prognostičke pogreške tržišta $i$ koji dolazi od inovacija na tržištu $j$. Stoga su zbrojevi stupaca Tablice 1. (osim dijagonale) direktni doprinosi drugima (označeni s $O d$ ), a zbrojevi redova (osim dijagonale) direktni doprinosi ostalih zemalja (označeni s Prema). Razlika „Prema minus $O d^{\prime \prime}$ označava neto efekt prelijevanja.

Tablica 1. Tablica prelijevanja šokova

\begin{tabular}{|c|c|c|c|c|c|c|c|c|c|}
\hline & CRO & GER & ITA & USA & FRA & SPA & RUS & SWE & Od \\
\hline CRO & 77,38 & 2,58 & 6,64 & 2,14 & 1,65 & 2,87 & 0,91 & 5,83 & 2,83 \\
\hline GER & 2,04 & 43,10 & 4,86 & 15,96 & 11,73 & 12,67 & 0,70 & 8,95 & 7,12 \\
\hline ITA & 1,20 & 5,66 & 58,52 & 11,05 & 10,20 & 6,37 & 0,45 & 6,55 & 5,19 \\
\hline USA & 0,74 & 14,66 & 5,30 & 47,61 & 10,74 & 12,52 & 0,26 & 8,16 & 6,55 \\
\hline FRA & 0,94 & 10,39 & 10,29 & 9,48 & 50,49 & 11,35 & 0,41 & 6,65 & 6,19 \\
\hline SPA & 1,54 & 8,8 & 7,69 & 11,65 & 11,77 & 49,78 & 0,58 & 8,18 & 6,28 \\
\hline RUS & 1,21 & 4,83 & 3,90 & 1,54 & 0,66 & 0,61 & 82,45 & 4,79 & 2,19 \\
\hline SWE & 1,56 & 7,24 & 5,00 & 8,87 & 8,27 & 7,79 & 0,19 & 59,08 & 5,12 \\
\hline Prema & 1,16 & 6,77 & 5,46 & 7,59 & 6,88 & 7,03 & 0,44 & 6,14 & Ukupno \\
\hline Neto & $-1,67$ & $-0,35$ & 0,27 & 1,04 & 0,69 & 0,75 & $-1,75$ & 1,02 & 41,47 \\
\hline
\end{tabular}

Izvor: izračun autora

Indeks prelijevanja za cijeli uzorak iznosi $41,47 \%$, što znači da je, u prosjeku, malo više od dvije petine varijance prognostičke pogreške za osam analiziranih zemalja objašnjeno prelijevanjima šokova u ekonomskoj neizvjesnosti između promatranih zemalja. Može se uočiti da šokovi u varijabli CRO objašnjavaju 77,38 \% vlastite varijance iste, dok se primjerice šokovi u varijabli ITA preliju u varijablu CRO tako da se 6,64 \% varijance varijable CRO objašnjava šokovima u ITA-i. Na taj način varijabla CRO najmanje šokova primi iz varijable RUS jer se samo 0,91 \% varijance varijable CRO može objasniti šokovima u RUS-u. Uočava se kako se među svim promatranim varijablama najveće direktno prelijevanje šokova u neizvjesnosti događa od varijable USA prema GER jer se čak 15,96\% varijance varijable GER može objasniti šokovima u USA-i. Iz tog razloga može se zaključiti da ekonomska neizvjesnost u SAD-u može najviše doprinijeti prognoziranju ekonomske neizvjesnosti u Njemačkoj. Iz analize se može zaključiti da je u promatranom uzorku varijabla USA najveći neto prenositelj šokova $(1,04 \%)$, dok je RUS najveći neto primatelj šokova $(-1,75 \%)$, a slijedi je CRO $(-1,67 \%)$. S obzirom na to da je hrvatska ekonomija najotvorenija od svih razmatranih gospodarstava (v. Tablicu 2.), ne čudi činjenica da se Hrvatska pokazala izrazito osjetljivom na inozemne šokove neizvjesnosti. 
Tablica 2. Udio vanjskotrgovinske razmjene u BDP-u u 2020. godini

\begin{tabular}{|c|c|c|c|c|c|c|c|}
\hline CRO & GER & ITA & USA & FRA & SPA & RUS & SWE \\
\hline 90,55 & 81,11 & 55,32 & 23,39 & 57,77 & 59,77 & 46,08 & 84,53 \\
\hline
\end{tabular}

Izvor: World Bank Development Indicators

Sažetak rezultata Tablice 1. pokazuje da je ukupan indeks prelijevanja relativno velik, usprkos tome što su direktna prelijevanja Od i Prema relativno male magnitude.

Metodom pomičnih prozora duljine 36 mjeseci procijenjen je ukupan indeks prelijevanja šokova za analizirane varijable u VAR modelu. Na taj način razmotrit će se postoje li značajne promjene u ukupnome prelijevanju tijekom promatranog razdoblja. Pomičan ukupan iznos prelijevanja prikazan je na Grafikonu $1^{3}$. Može se uočiti da su najveće vrijednosti indeksa u vrijeme globalne financijske krize. Nagli skokovi vrijednosti indeksa vidljivi su u periodu europske dužničke krize, u periodu koji se podudara s referendumom o Brexitu te u koronakrizi.

Grafikon 1. Pomični ukupni indeks prelijevanja

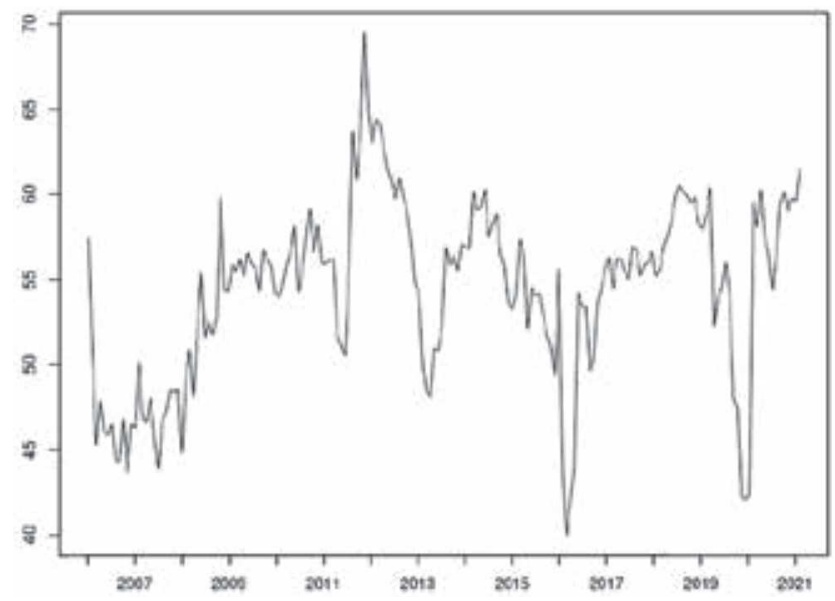

Izvor: izračun autora

U nastavku se promatra kako se šokovi u varijabli EPU indeks jedne zemlje prelijevaju u varijablu EPU indeks drugih zemalja tijekom vremena, odnosno koje zemlje su u kojem periodu bile neto prenositelji, a koje neto primatelji šokova. Duljina pomičnog prozora je 36 mjeseci, a rezultati su prikazani na Grafikonu 2. U razdoblju globalne financijske krize, kao što je bilo očekivano, SAD je bio najveći neto prenositelj šokova, dok je Hrvatska među promatranim zemljama bila najveći primatelj šokova. Može se vidjeti da je u gotovo cijelom razdoblju nakon 2008. godine Italija bila neto primatelj šokova, kao i u koronakrizi. Slično vrijedi i za Rusiju, Španjolsku i Francusku. S druge strane, u razdoblju koronakrize, SAD

3 Na ordinatama svih grafikona prikazane su vrijednosti indeksa iz naslova pojedinog grafikona. 
i Njemačka bili su glavni prenositelji šokova. Švedska je, pak, bila najveći neto prenositelj šokova između 2012. i 2014. godine.

Grafikon 2. Pomični neto indeksi prelijevanja šokova
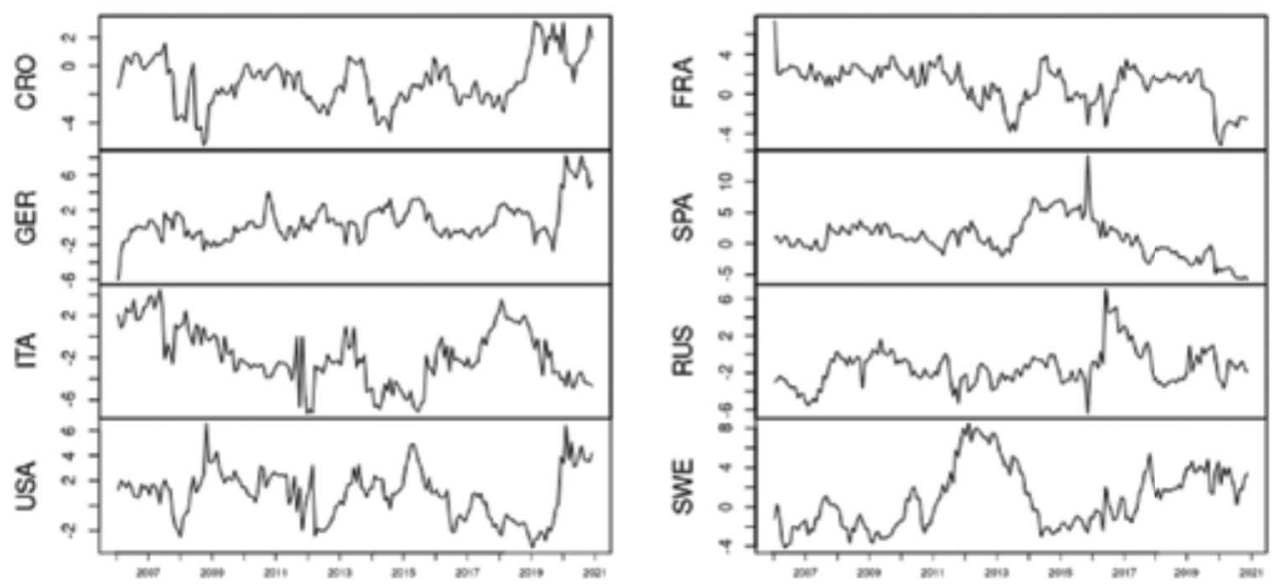

Izvor: izračun autora

Konačno, prije diskusije na temelju svih rezultata napravljena je provjera robusnosti rezultata. Diebold i Yilmaz $(2009,2012)$ savjetuju promjenu duljine pomičnog prozora kako bi se ispitala validnost prethodnih nalaza. Rezultati su robusni ako vrijednosti svih indeksa slijede sličnu dinamiku. $U$ analizi je napravljena promjena duljine od 32 do 39 mjeseci.

Kao što je vidljivo na Grafikonu 3., dinamika indeksa slična je za sve promatrane duljine pomičnih prozora. Iz toga se zaključuje da su dobiveni rezultati robusni. 
Grafikon 3. Ukupni indeksi prelijevanja s obzirom na različitu duljinu pomičnih prozora
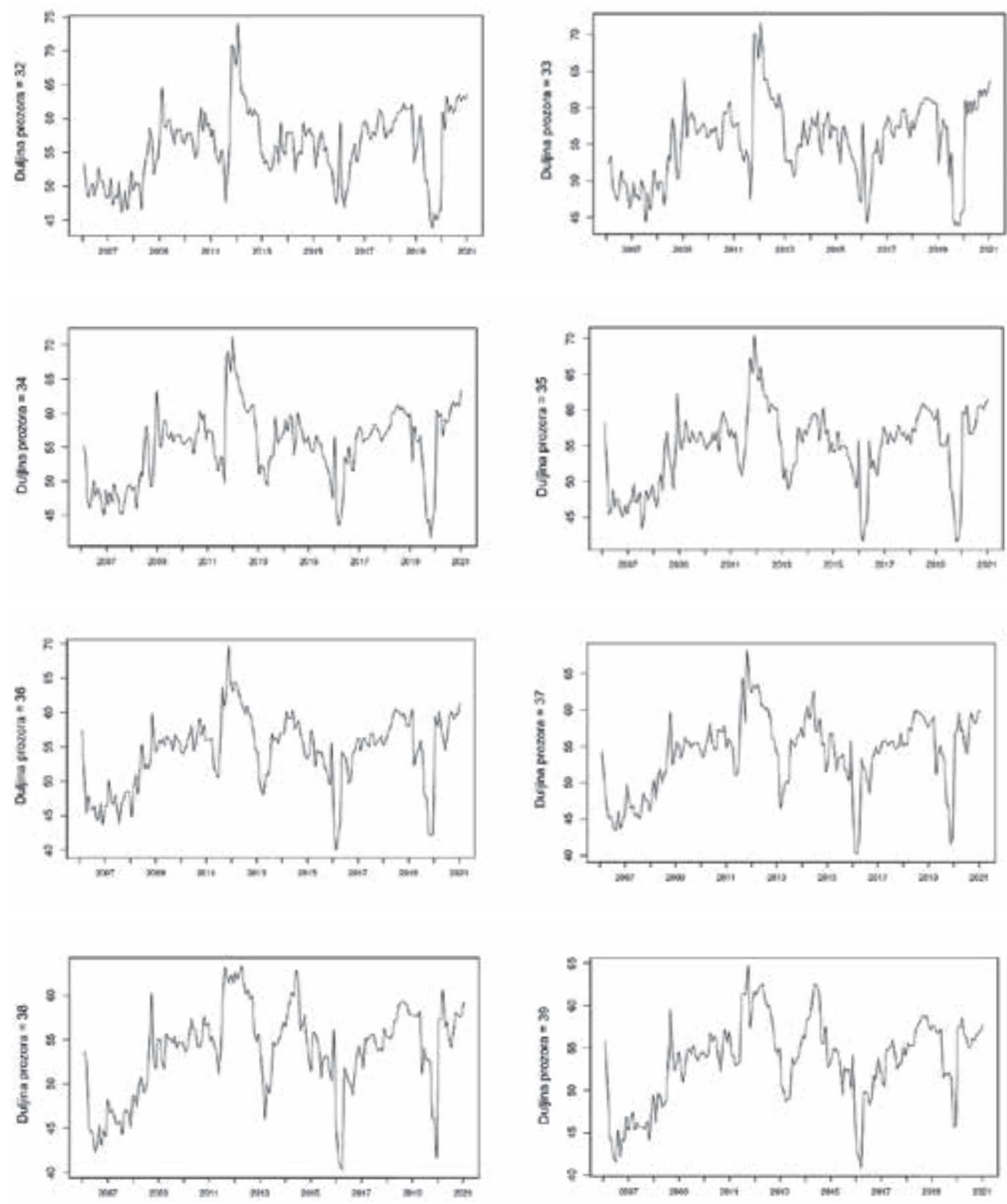

Izvor: izračun autora

Iako se rezultati o učincima prelijevanja ekonomske neizvjesnosti ne mogu generalizirati jer se promatrane zemlje ponašaju dosta heterogeno, može se primijetiti da su za vrijeme većih kriza velika gospodarstva većinom bila neto prenositelji šokova, dok su mala otvorena gospodarstva bila neto primatelji. 
Neizvjesnost je kontraciklična, što znači da raste u recesijama i smanjuje se u periodima gospodarskog rasta, te je vodeća varijabla u odnosu na BDP (Arčabić 2015; Lolić, Sorić i Logarušić 2021). Iz tog se razloga implikacije ovih rezultata, prije svega, odnose na važnost adekvatnog komuniciranja nositelja ekonomske politike, kao i pravovremenog informiranja javnosti i ostalih uključenih strana (poduzeća, investitora itd.) o planiranim promjenama u ekonomskoj politici. Budući da se EPU indeksi izračunavaju na mjesečnoj razini, njihovo redovito praćenje može biti korisno za nositelje ekonomske politike. Naime, gospodarstva koja su povezanija s određenim drugim zemljama, mogu promptno reagirati na skokove u ekonomskoj neizvjesnosti u tim zemljama i tako smanjiti negativan utjecaj rasta neizvjesnosti u okolini. Za Hrvatsku kao malu, otvorenu ekonomiju od iznimne je važnosti pratiti promjene neizvjesnosti. Izostanak adekvatnog komuniciranja u razdoblju visoke neizvjesnosti može negativno utjecati na gospodarstvo, što se moglo vidjeti u globalnoj financijskoj krizi kada se tadašnja vlast odbijala suočiti s krizom sve do studenoga 2008. godine (Sorić i Lolić 2017).

\section{ZAKLJUČAK}

Hrvatska je mala, otvorena ekonomija te je kao takva iznimno osjetljiva na inozemne šokove. Iz tog se razloga u ovome radu analiziraju učinci prelijevanja ekonomske neizvjesnosti između Hrvatske, Njemačke, Italije, SAD-a, Francuske, Španjolske, Rusije i Švedske. U analizi je korišten EPU indeks za sve zemlje u razdoblju od siječnja 2003. do ožujka 2021. godine. Analiza je provedena pomoću indeksa prelijevanja, što je omogućilo izračunavanje direktnih učinaka prelijevanja, koji su potom agregirani u jedinstveni pokazatelj ukupnog prelijevanja. Navedeno je korišteno kako bi se prikazala razina povezanosti između zemalja u uzorku.

Kad se suoče s neizvjesnošću, gospodarski subjekti mijenjaju svoje ponašanje i proces donošenja odluka. Zbog povećanog opreza poduzeća pri donošenju odluka, financijskih posrednika te posljedično otežanog financiranja, realni sektor trpi posljedice povećane neizvjesnosti. Financijski sektor također je pogođen, što je vidljivo iz averzije ulagača prema

riziku te posljedično pada prometa na tržištu kapitala. Takve odluke mogu biti katalizatori recesije, što dodatno ukazuje na potrebu za proučavanjem neizvjesnosti. Na temelju provedene empirijske analize zaključuje se da je više od dvije petine varijance prognostičke pogreške promatranog uzorka objašnjeno prelijevanjima šokova u ekonomskoj neizvjesnosti između promatranih zemalja. Od svih promatranih zemalja najveći udio u ukupnom indeksu ima SAD te je ujedno i najveći neto prenositelj šokova. S druge strane, najveći neto primatelji šokova su Rusija i Hrvatska. Opće je poznato da je neizvjesnost kontraciklična, što znači da raste u recesijama i smanjuje se u periodima gospodarskog rasta, te je vodeća varijabla u odnosu na BDP. Proučavanje neizvjesnosti i razumijevanje njezine dinamike donosi više informacija donositeljima odluka, što može smanjiti rizik poslovanja. Adekvatna komunikacija i pravovremeno informiranje mogu spriječiti katastrofalne posljedice za gospodarstvo kakvima smo svjedočili tijekom globalne financijske krize.

Uvjetno na kvantifikaciju EPU indeksa u zemljama geografski bliskima Hrvatskoj, prijedlog za buduća istraživanja jest analiza učinaka prelijevanja između Hrvatske i navedenih zemalja. 


\section{LITERATURA}

1. Arčabić, V. (2015). Djelovanje neizvjesnosti na bankarsko tržište u Republici Hrvatskoj. EFZG Working Paper Series, (15-03), str. 1-34. [online] Dostupno na: https:// hrcak.srce.hr/file/203426 [pristupljeno 4. 10. 2021.].

2. Arčabić, V. (2020). Koronakriza i što Hrvatska može naučiti iz dosadašnjih recesija, u: Tica, J. i Bačić, K. (ur.), Ekonomska politika Hrvatske u 2021. godini - Hrvatska poslije pandemije (str. 21-58), Zagreb: Hrvatsko društvo ekonomista.

3. Arčabić, V. i Škrinjarić, T. (2019). Synchronization and spillovers of business cycles in the European Union, u: Šimurina, J., Načinović Braje, I. i Pavić, I. (ur.), Proceedings of FEB Zagreb $10^{\text {th }}$ International Odyssey Conference on Economics and Business. (str. 113-127.), Zagreb: Faculty of Economics \& Business.

4. Bach, S. (2014). Financijska kriza i kreditni rejtinzi država. Međunarodne studije, 14 (3/4), str. 10-28.

5. Baker, S., Bloom, N. i Davis, S. J. (2016). Measuring Economic Policy Uncertainty. Quarterly Journal of Economics, 131(4), str. 1593-1636.

6. Baker, S., Bloom, N. i Davis, S. J. (2021). Economic Policy Uncertainty. [online] Dostupno na: https://www.policyuncertainty.com/ [pristupljeno 4. 10. 2021.].

7. Balcilar, M., Demirer, R., Gupta, R. i Van Eyden, R. (2017). The impact of US policy uncertainty on the monetary effectiveness in the Euro area. Journal of Policy Modeling, 39(6), str. 1052-1064.

8. Colombo, V. (2013). Economic policy uncertainty in the US: does it matter for the Euro area?. Economics Letters, 121(1), str. 39-42.

9. Čižmešija, M., Lolić, I. i Sorić, P. (2017). Economic policy uncertainty index and economic activity: what causes what?. Croatian Operational Research Review, 8(2), str. 563-575.

10. Ć́orić, T., Šimović, H. i Deskar-Škrbić, M. (2015). Monetary and fiscal policy mix in a small open economy: the case of Croatia. Economic Research-Ekonomska Istraživanja, 28(1), str. 407-421.

11. Diebold, F. X. i Yilmaz, K. (2009). Measuring Financial Asset Return and Volatility Spillovers with Application to Global Equity Markets. The Economic Journal, 119(534), str. 158-171.

12. Diebold, F. X. i Yilmaz, K. (2012). Better to Give than to Receive: Predictive Directional Measurement of Volatility Spillovers. International Journal of Forecasting, 28(1), str. 57-66.

13. Gabauer, D. i Gupta, R. (2018). On the transmission mechanism of country-specific and international economic uncertainty spillovers: Evidence from a TVP-VAR connectedness decomposition approach. Economics Letters, 171, str. 63-71.

14. Ghirelli, C., Pérez, J. J. i Urtasun, A. (2019). A new economic policy uncertainty index for Spain. Banco de España Documentos de Trabajo, (1906), str. 1-24. [online] Dostupno na: https://core.ac.uk/download/pdf/322617751.pdf [pristupljeno 4. 10. 2021.] 
15. Gupta, R., Lau, C. K. M., Nel, J. A. et al. (2020). Monetary policy uncertainty spillovers in time and frequency domains. Economic Structures, 41(9).

16. Huidrom, R., Ayhan Kose, M., Matsuoka, H. i Ohnsorge, F. L. (2019). How important are spillovers from major emerging markets?. International Finance, 23(1), str. 47-63.

17. Jovančević, R., Arčabić, V. i Globan, T. (2012). Prijenos poslovnih ciklusa zemalja Europske unije na Republiku Hrvatsku. Ekonomski pregled, 63(1-2), str. 3-21.

18. Koop, G., Pesaran, M. H. i Potter, S. M. (1996). Impulse response analysis in non-linear multivariate models. Journal of Econometrics, 74(1), str. 119-147.

19. Krznar, I. i Kunovac, D. (2010). Utjecaj vanjskih šokova na domaću inflaciju $i$ BDP. [online] Dostupno na: https://www.hnb.hr/documents/20182/121348/i-028.pdf/ 073c5b08-ce30-4ba4-82fa-a95a66ff8b4a [pristupljeno 4. 10. 2021.]

20. Kunovac, D. (2013). Trošak zaduživanja odabranih zemalja Europske unije i Hrvatske - uloga prelijevanja vanjskih šokova. [online] Dostupno na: https://www.hnb.hr/ documents/20182/121666/i-041.pdf/aa084339-76ca-443f-b460-8ced5c3b0751 [pristupljeno 4. 10. 2021.]

21. Lanne, M. i Lütkepohl, H. (2010). Structural vector autoregressions with nonnormal residuals. Journal of Business and Economic Statistics, 28, str. 159-168.

22. Lolić, I., Sorić, P. i Logarušić, M. (2021). Economic Policy Uncertainty Index Meets Ensemble Learning. Computational Economics. https://doi.org/10.1007/s10614-02110153-2

23. Luk, P., Cheng, M., Ng, P. i Wong K. (2018). Economic policy uncertainty spillovers in small open economies: The case of Hong Kong. Pacific Economic Review, 25(1), str. 21-46.

24. Lütkepohl, H. (2011). Vector Autoregressive Models. Economics Working Paper ECO 2011/30. European University Institute. [online] Dostupno na: http://cadmus.eui.eu/ bitstream/handle/1814/19354/ECO_2011_30.pdf?sequence=1 [pristupljeno 4. 10. 2021.]

25. Nadoveza, O. i Šimurina, J. (2012). Utjecaj gospodarskih ciklusa na razvoj malog otvorenog gospodarstva: primjer Hrvatske, Slovenije, Slovačke i Mađarske, u: Družić, G. i Družić, I. (ur.) Razvojna strategija malog nacionalnog gospodarstva u globaliziranom svijetu, Zagreb: HAZU i Ekonomski fakultet Zagreb, str. 353-385.

26. Pesaran, M. H. i Shin, Y. (1998). Generalized impulse response analysis in linear multivariate models. Economics Letters, 58(1), str. 17-29.

27. Sorić, P. i Lolić, I. (2017). Economic uncertainty and its impact on the Croatian economy. Public Sector Economics, 41(4), str. 443-477.

28. Sum, V. (2012). Economic Policy Uncertainty and Stock Market Performance: Evidence From the European Union, Croatia, Norway, Russia, Switzerland, Turkey and Ukraine. Journal of Money, Investment and Banking, 25, str. 99-104.

29. Škrabić Perić, B. i Sorić, P. (2018). A note on the „Economic policy uncertainty index“. Social indicators research, 137(2), str. 505-526.

30. Škrinjarić, T. i Orlović, Z. (2020). Economic policy uncertainty and stock market spillovers - case of selected CEE markets. Mathematics, 8(7), str. 1-33. 
31. Škrinjarić, T. i Šego, B. (2019). Risk connectedness of selected CESEE stock markets: spillover index approach. China Finance Review International, 10(4), str. 447-472.

32. Yilmaz, K. (2009). International business cycle spillovers, TÜSIAD - Koç University Economic Research Forum Working Paper Series, (0903), str. 1-31. [online] Dostupno na: https://www.econstor.eu/bitstream/10419/45458/1/599164492.pdf [pristupljeno 4. 10. 2021.]

33. Yin, L. i Han, L. (2014). Spillovers of macroeconomic uncertainty among major economies. Applied Economics Letters, 21(13), str. 938-944. 